\title{
Determining the Effect of Synthetic-based Varnish and Impregnation on Wood's Shear Strength under Cold Climate Conditions
}

\author{
Şemsettin Doruk
}

\begin{abstract}
Glue shear strength and wood preservatives play an important role in the longevity of engineered wood products. The effects of factors such as UV rays, humidity, and temperature on wooden materials are known. However, it is not known what effects sub-zero temperatures have on wood material and how wood preservatives play a role. This study determined the effects of syntheticbased varnish and impregnation on shear strength in cold climatic conditions. Variables including glue type, ambient temperature, tree type, and process type were investigated. Wood laminate test samples were produced for this purpose, and water repellent impregnation material and synthetic-based varnish were used as wood preservatives. Experimental samples were kept in a cold air cabinet at $\left(-15^{\circ} \mathrm{C}\right)$ and $\left(-30^{\circ} \mathrm{C}\right)$ temperature for 90 days. Samples kept in different temperature conditions were subjected to a pull experiment in a parallel $(/ /)$ direction to the fibers under static load. As the ambient temperature decreased, the shear strength decreased $\left(-15^{\circ} \mathrm{C}: 8,960 \mathrm{~N} / \mathrm{mm}^{2}\right.$ $\left.,-30^{\circ} \mathrm{C}: 8,025 \mathrm{~N} / \mathrm{mm}^{2}\right)$. When the performance of wood preservation elements were examined, it was determined that the varnish process $\left(8,875 \mathrm{~N} / \mathrm{mm}^{2}\right)$ and the impregnation process $\left(8,691 \mathrm{~N} / \mathrm{mm}^{2}\right)$ were not statistically significant, at $12 \%$ and $10 \%$, respectively.
\end{abstract}

Keywords: Shear strength; Cold temperatures; Varnish; Linseed oil; Impregnation

Contact information: Karabük Ü. Faculty of Forestry, Forest End. Eng., Karabük, Turkey;

* Corresponding author: settindoruk@karabuk.edu.tr

\section{INTRODUCTION}

Wood has many good qualities, including its thermal properties, its high resistance, easy processing, and ability to accept paint and varnish and to absorb sound. It creates a warm and pleasant atmosphere where it is used aesthetically, which makes it a popular material to use both naturally and with the necessary preservatives. Wood is used intensively as auxiliary material with other building materials in addition to its individual use in all kinds of outdoor conditions. Therefore, applications for turning wood into a durable material by using it in suitable conditions have gained traction. These engineering wood applications include glued laminated wood (glulam), laminated veneer lumber (LVL), and cross-laminated timber (CLT), which are common in Europe and North America. There are concerns about glue quality and bond line integrity in these products, which requires adhesive connections used in processed wood products to be as strong and durable as the wood itself. In particular, the resistance properties of processed wood products are affected by both low temperatures and significant temperature changes. This problem is particularly important in regions such as Scandinavia, Greenland, the Alps, Canada, Alaska, Russia, Mongolia, northern China, and northern Japan. Wood construction in these areas is frequently exposed to low temperatures for long periods of the year. 
However, thermal conditions are often not taken into account in the design and estimation of the service life of wood constructions (Wang et al. 2016).

Wood and glues have very different coefficients of swelling and shrinkage. The adhesion line of most glues is more brittle than wood. If the difference in thermal properties of wood and glue is not compensated, performance problems may occur when the structure is exposed to large temperature changes. In these cases, the design must compensate for the different movements of components while maintaining structural integrity. Good performance of glue lines at high temperatures has been documented (Frangi et al. 2004; Falkner and Teutsch 2006; Clauss et al. 2011; Wang et al. 2016). However, although some studies of wooden bridges in cold climates have been reported, there is not much information about the stability of glue lines at low temperatures, especially extreme cold temperatures (Kainz and Ritter 1998; Wacker 2003, 2009).

In high-performance products, leaving the material unprotected against the effects of open-air leads to defects, such as loss of color, caused by factors such as sunlight (UV rays), rain, wetting and drying, fiber loss due to cracks, and the gradual erosion of the damaged surface, as well as weakening of the glue line. It is important to reduce these negative effects by rationally using the appropriate wood species under suitable outdoor conditions, to extend the life of the wood material with appropriate impregnation methods, and to apply top surface treatments. Extending the life of the wood material might help meet the country's needs and provide foreign currency input by exporting these wood materials.

The most commonly used impregnations contain inorganic toxic substances, such as copper, chromium, arsenic, and their compounds. Currently, increasing cases of cancer and negative environmental effects have spurned a push for organic wood preservatives that will not negatively affect the environment and health. One of these preservatives is linseed oil. Linseed oil, traditionally used as a surface coating, is a natural, organic chemical that can be used as a wood preservative. It can penetrate the cell walls well enough during the impregnation process, reduce hygroscopic movements in the wood, act as a stabilizer, and since it is considered hydrophobic, it is regarded as a unique chemical. At the same time, during impregnation, linseed oil fills gaps such as tracheid lumens, rays, and cracks caused by the drying process (Olsson et al. 2001).

When observing the studies about the negative effects of the external environment on the material, decaying effects such as photodegradation with UV, washing with rain, biological activity (fungus, etc.) have been the primarily investigated subjects. There have been some studies, albeit few, conducted on the effect of sub-zero temperature on the mechanical properties of wood material. Wang et al. (2016) tested the experiment samples made of Norway spruce (Picea abies) wood, which they combined with polyurethane (PUR), polyvinyl acetate (PVAc), emulsion-polymer-isocyanate (EPI), melamine-formaldehyde (MF), phenol-resorcinol-formaldehyde (PRF), melamine-urea-formaldehyde1 (MUF1), and melamine-urea-formaldehyde2 (MUF2) glues, in six different temperature environments $\left(20,-20,-30,-40,-50\right.$, and $\left.-60{ }^{\circ} \mathrm{C}\right)$. In general, temperature changes have significantly affected the glue shear strength. The researchers reported that the shear strength decreased with the decrease in temperature, and in general, the lowest change was just below 20\% in samples with PRF and PVAc glue, and between 25-27\% in samples with other glue types. Wang et al. (2015), also, compared the values of the 12-hour and 6-day tests of the experiment samples under temperature cycles $\left(-20\right.$ and $\left.0{ }^{\circ} \mathrm{C}\right)$ and stated that the shear strength of the samples exposed to the same temperature decreases as the time increases. 
Laminated samples, which were from the wood of Scotch pine (Pinus sylvestris L.), Eastern beech (Fagus orientalis L.), and Sessile oak (Quercus petraea Liebl), glued with PVAc-D4 and VTKA adhesives were impregnated with synthetic exterior varnish and a water repellent impregnation agent. The prepared experiment samples were exposed to open weather conditions for one year in Ankara (average min. temp: $-2.7^{\circ} \mathrm{C}$, average max. temp: $30.5^{\circ} \mathrm{C}$ ). At the end of this period, a tensile test parallel to the fibers was applied to the experiment samples. The lamination layer has the highest shear strength in varnished samples and the lowest in control samples. It has been determined that the impregnation process provides $18 \%$ and the varnishing process provides $30 \%$ anti-degradation benefits (Doruk 2009).

In their study, in which Szmutku et al. (2013) investigated the effects of freezing on the strength and stiffness of green spruce, they found that freezing rate had a significant effect on the strength/stiffness of the test specimens once thawed. It was also found that the post-frozen strength/stiffness of the specimens decreased with decreasing freezing rate due to the deleterious effects of larger ice crystals observed in the specimens frozen at slower rates. However, their study did not include an investigation on the effect of freezing rate on the frozen properties of the wood.

The effect of temperature (including cold temperatures) on the modulus of elasticity and bending strength of wood-based panels has also been investigated. Ayrilmis et al. (2010) investigated the effects on plywood, medium density fiberboard, and oriented strand board, while Bekhta and Marutzky (2007) and Suzuki and Saito (1987) investigated the effects on particle board. Similar to what was found for the strength and stiffness of clear wood, the strength and stiffness of the wood panels was observed to increase with decreasing temperature.

The increased strength and stiffness of wood with decreasing temperatures observed in this previous research may be due to the formation of ice crystals within the wood cells, as was postulated by Schmidt and Pomeroy (1990). Further, these effects may also be attributed to the stiffening of cellulose fibrils from the formation of ice, similar to the effects of adhesives (Ayrilmis et al. 2010). The cited authors also concludes that for wood products containing adhesives, the cold temperature effects may also be attributed to observed increase in the strength and stiffness of the adhesives used in the products. The continued strength/stiffness gain below the freezing point of water may be explained with the fact that ice gives rise to an increase in strength/stiffness with decreasing temperature (Petrovic 2003).

Shear and hardness values were measured at 20,0 , and $-40{ }^{\circ} \mathrm{C}$ on laminated beams in different moisture levels. Temperature was observed to affect the failure mechanism of the beams, with the beams tested at 0 and $20{ }^{\circ} \mathrm{C}$ failing in shear and the beams tested at minus $40{ }^{\circ} \mathrm{C}$ failing in tension. Further, the strengths of the beams and their stiffnesses were observed to increase with decreasing temperature, with these effects being more pronounced in the higher moisture content beams (Drake et al. 2015).

The samples were subjected to tensile and shear strength tests after climatizing, holding in cold water, boiling, and alternating boiling processes by using DesmodurVTKA glue for bonding experimental samples prepared from wood of Scotch pine, Eastern beech, and Sessile oak. The highest tensile strength was obtained $\left(11.73 \mathrm{~N} / \mathrm{mm}^{2}\right)$ after 24 h. of cold water soaking in Sessile oak compared to the other control samples. Also, it is reported that at the end of the long-term alternating boiling process, there is an average of $50 \%$ loss of resistance at the adhesion points. It has been explained that Desmodur-VTKA glue can be used in dry or humid indoor and outdoor areas (Özçifçi et al. 1997). 


\section{EXPERIMENTAL}

\section{Wood Material}

In this study, 2-mm thick Eastern beech (Fagus orientalis Lipsky), Sessile oak (Quercus petraea Lieble), and yellow pine (Pinus sylvestris) veneers were used. Veneers were supplied by a random purchase method. Extra attention was given to ensure that the veneers were made of flawless, smooth fiber wood material.

\section{Glue}

Two-component polyvinyl acetate (PVAc-D4), polyurethane-based vinyl tree ketonol acetate (VTKA) glue was used for bonding the samples. PVAc - D4 glue was brought to D4 adhesion quality according to BS EN 204 (1991) by further increasing the moisture resistance with the addition of the PVAc glue hardener. The technical characteristics of the glues used are given in Table 1.

Table 1. Technical Characteristics of the Glues Used (https://www.kleiberit.com)

\begin{tabular}{|l|l|l|}
\hline Properties of the Glue & \multicolumn{1}{|c|}{ VTKA } & \multicolumn{1}{c|}{ PVAc-D4 } \\
\hline Base & Polyurethane & PVAc \\
\hline Specific gravity & $1.08 \mathrm{~g} / \mathrm{cm}^{3}$ & $\begin{array}{l}\text { Comp. A: } 1.10 \mathrm{~g} / \mathrm{cm}^{3}, \\
\text { Comp. B: } 1.13 \mathrm{~g} / \mathrm{cm}^{3}\end{array}$ \\
\hline $\begin{array}{l}\text { Viscosity at } 20^{\circ} \mathrm{C} \\
\text { Brookfield RVT }\end{array}$ & $\begin{array}{l}\text { Sp. } 7 / 5 \mathrm{rpm}: 120 \mathrm{~N} / \mathrm{mm}^{2} \\
\text { Sp. } 7 / 50 \mathrm{rpm}: 35 . \mathrm{N} / \mathrm{mm}^{2}\end{array}$ & spindle $6 / 20 \mathrm{rpm}: 13 \pm 2 \mathrm{~N} / \mathrm{mm}^{2}$ \\
\hline pH-value, (w/o hardener) & - & 3.0 \\
\hline Color & Transparent to yellowish-white & White \\
\hline
\end{tabular}

\section{Wood Preservatives}

Water repellent impregnation material and synthetic-based varnish were applied to the experimental samples. Water repellent impregnation material is an organic solvent. The impregnation solution contains 3\% paraffin, 10\% linseed oil, 87\% grain alcohol (Var 2001). Paraffin with linseed oil is economical and preferred because it is harmless to humans and other living things. Synthetic based varnish, which is often applied especially in open areas, was chosen. This is a colorful varnish type that preserves wood material surfaces against all kinds of bad weather conditions. With semi-transparent and covering varieties, with color options, varnish has ideal usage opportunity for all kinds of interior and exterior joinery, facade cladding, and garden furniture (https://www.hemel.com.tr/)

\section{Preparation of Experimental Samples}

Experimental samples were constructed of 10 layers whose fiber directions were parallel to each other. Vinyl tree ketonol acetate (VTKA) and PVAC - D4 glue, which are known their durability to wet places and to environments exposed to external influences, were used to bonding of layers. Glue solution was applied to only one surface of layers with 180 to $200 \mathrm{~g} / \mathrm{m}^{2}$, and they were pressed as follows by hydraulic hot press: PVAC D4 glue at the $80{ }^{\circ} \mathrm{C}$ temperature, $1.2 \mathrm{~N} / \mathrm{mm}^{2}$ pressure and $20 \mathrm{~min}$., VTKA glue at the 20 ${ }^{\circ} \mathrm{C}$ temperature, $1.2 \mathrm{~N} / \mathrm{mm}^{2}$ pressure and $60 \mathrm{~min}$., based on the recommendations of the suppliers. Laminated panels were passed through sandpaper and rubbed on both surfaces with emery No. 180, followed by calibration of the thickness. The draft samples were cut to the measurements specified in TS EN 205 (2004) for shear strength experiment samples 3 tree species (Sessile oak, Eastern beech, Scotch pine), 2 glue type (PVAc, VTKA), 2 
ambient temperature $\left(-15^{\circ} \mathrm{C},-30^{\circ} \mathrm{C}\right), 2$ wood preservation type (Impregnation, varnish) + 1 control and 8 tekerrür olmak üzere toplam $288(3 \times 2 \times 2 \times 3 \times 8)$ deney örneği hazırlanmıştır. Then they were kept in a conditioning cabinet with a temperature of $20 \pm 2{ }^{\circ} \mathrm{C}$ and relative humidity of $65 \pm 5 \%$ until they reached an invariant weight.

\section{Wood preservative application}

The impregnation process of the test samples was performed according to the principles of ASTM D 1413-76. Accordingly, the samples impregnated with water repellent were left to diffuse in solution at normal atmospheric pressure for $60 \mathrm{~min}$. after they were applied pre-vacuum equivalent to $60 \mathrm{~cm} \mathrm{HgP-1P}$ (HgP-1P vacuum) for 60 minutes. The impregnated samples were kept in the conditioning cabinet at $60 \pm 5 \%$ relative humidity and $20 \pm 2{ }^{\circ} \mathrm{C}$ until the equilibrium moisture was reached in order for the solution to evaporate and reach air-dry state.

After the samples to be applied varnish reached air-dry state in an air-conditioning cabinet at $60 \pm 5 \%$ relative humidity and $20 \pm 2{ }^{\circ} \mathrm{C}$, and then varnish was applied with a brush in 2 coats one day apart. A fine sandpaper has been applied between the layers. (www.hemel.com.tr).

\section{Keeping the test samples in cold weather condition}

Considering that the average duration of the winter season is three months, control and samples with preservative were kept in a cold air cabinet at $\left(-15^{\circ} \mathrm{C}\right)$ and $\left(-30{ }^{\circ} \mathrm{C}\right)$ for 90 days. Tensile tests were carried out at the end of the period.

\section{Air Dry Density and Determination}

In the determination of air-dry density, samples with the dimensions of $20 \mathrm{x} 20 \mathrm{x}$ $30 \mathrm{~mm}$ were used according to TS 2472. Accordingly, the experiment samples reached the invariant weight and dimensional stability after being kept at $20 \pm 2{ }^{\circ} \mathrm{C}$ temperature and 65 $\pm 5 \%$ relative humidity. The samples were then weighed on an analycal scale with a precision of $0.01 \mathrm{~g}$. After their volume was determined by measuring their dimensions with a caliper with a precision of $\pm 0.01 \mathrm{~mm}$, the air-dry density $\left(\delta_{12}\right)$ was calculated using by the following equation,

$$
\delta_{12}=M_{12} / V_{12} \quad \mathrm{~g} / \mathrm{cm}^{3}
$$

where $M_{12}$ is the sample air-dry weight $(\mathrm{g})$, and $V_{12}$ is the sample air-dry volume $\left(\mathrm{cm}^{3}\right)$.

\section{Retention Rate (\%)}

The impregnation of experiment samples was carried out under the conditions specified in ASTM D 1413-07 (2007). After impregnation, the samples were kept for 10 to 15 days under room conditions for the organic solvent to evaporate and were conditioned again in the air conditioning cabinet until the air-dry reached $12 \pm 1 \%$ equilibrium humidity. Thus, the dry matter percentage held in each sample was calculated as follows,

$$
\mathrm{DMP}=\left[\left(M_{12} \mathrm{e}-M_{12}\right) / M_{12}\right] \times 100
$$

where DMP is the percentage of retention of dry matter $(\%), M_{12} \mathrm{e}$ is the air-dry weight after impregnation $(\mathrm{g})$, and $M_{12}$ is the air-dry weight before impregnation $(\mathrm{g})$. 


\section{Test Method}

The shear strength test was conducted per TS EN 205 (2004) to detach the sample along the glue line by applying a parallel, gradual tensile force to the layer surface with a loading speed of $2 \mathrm{~mm} / \mathrm{min}$. An example of a parallel force tensile to fibers (Fig. 1) is shown.

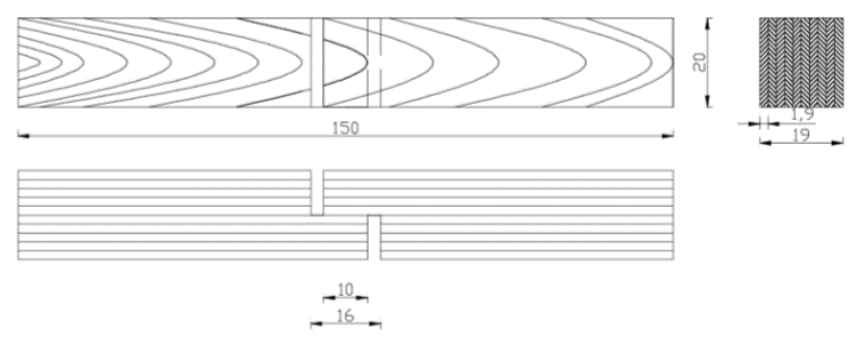

Fig. 1. Example of parallel force tensile to fibers

\section{RESULTS AND DISCUSSION}

\section{Air-dry Density and Retention Rate}

Dry air density and retention rates of experiment samples are presented in Table 2. Accordingly, in the laminated experiment samples, the density in the air-dry form was the highest in Eastern beech with VTKA glue $\left(0.76 \mathrm{~g} / \mathrm{cm}^{3}\right)$ and the lowest in the Scotch pine $\left(0.57 \mathrm{~g} / \mathrm{cm}^{3}\right)$. The highest retention rate was found in Scotch pine with VTKA glue $(25.75 \%)$ and the lowest in Eastern beech with PVAc-D4 glue (7.3\%).

Table 2. Dry Air Density and Retention Rates of Experiment Samples

\begin{tabular}{|l|c|c|c|}
\hline Tree Species & Glue type & $\boldsymbol{\delta}\left(\mathbf{g r} / \mathbf{c m}^{\mathbf{3}}\right)$ & $\boldsymbol{X}_{\text {Avg }}(\%)$ \\
\hline \multirow{2}{*}{ Sessile Oak } & PVAc-D4 & 0.72 & 11.27 \\
\cline { 2 - 4 } & VTKA & 0.67 & 10.46 \\
\hline \multirow{2}{*}{ Eastern Beech } & PVAc-D4 & 0.75 & 7.30 \\
\cline { 2 - 4 } & VTKA & 0.76 & 15.19 \\
\hline \multirow{2}{*}{ Scotch Pine } & PVAc-D4 & 0.58 & 25.75 \\
\cline { 2 - 4 } & VTKA & 0.57 & \multicolumn{2}{l}{} \\
\cline { 2 - 4 }$\delta_{12}$ air dry density, $X_{\text {Avg. }}(\%):$ Retention average value
\end{tabular}

\section{Analysis of Variance (ANOVA)}

Different shear strength values were measured from each of the experiments to determine the effects of synthetic based varnish and impregnation on shear strength at different ambient temperatures. A variance analysis was performed to determine whether these differences were purely coincidental or caused by other factors, and the effect of each factor on this response is presented in Table 3.

According to the variance analysis results, glue type/ambient temperature interaction (BD) and tree type/glue type/ambient temperature interaction (ABD) did not have a significant effect on shear strength $(\mathrm{P}<0.05)$, while all other factors and interactions had a significant effect. The Duncan test (HG) results of the effect on shear strength considering significant factors such as tree type, glue type, wood preservation type, and ambient temperature are given in Table 4. 
Table 3. Results of Variance Analysis for Tensile Adhesion Stress Parallel to Fibers $(/ /)$

\begin{tabular}{|l|c|c|c|l|l|}
\hline $\begin{array}{c}\text { Sources Of } \\
\text { Variance }\end{array}$ & $\begin{array}{c}\text { Degrees Of } \\
\text { Freedom }\end{array}$ & $\begin{array}{c}\text { Sum Of } \\
\text { Squares }\end{array}$ & Mean Square & F Value & P<0.05 \\
\hline Tree Type (A) & 2 & 692.828 & 346.414 & 411.8717 & $0,0000^{*}$ \\
\hline Glue Type (B) & 1 & 73.235 & 73.235 & 87.0737 & $0,0000^{*}$ \\
\hline AB & 2 & 67.686 & 33.843 & 40.2379 & $0,0000^{*}$ \\
\hline $\begin{array}{l}\text { Type of } \\
\text { Preservation (C) }\end{array}$ & 2 & 50.174 & 25.087 & 29.8275 & $0,0000^{*}$ \\
\hline AC & 4 & 67.525 & 16.881 & 20.0710 & $0,0000^{*}$ \\
\hline BC & 2 & 86.069 & 43.034 & 51.1661 & $0,0000^{*}$ \\
\hline ABC & 4 & 81.560 & 20.390 & 24.2430 & $0,0000^{*}$ \\
\hline Ambient & 1 & 62.916 & 62.916 & 74.8047 & $0,0000^{*}$ \\
\hline Temperature (D) & 2 & 16.102 & 8.051 & 9.5725 & $0,0001^{*}$ \\
\hline AD & 1 & 2.172 & 2.172 & 2.5823 & 0.1093 \\
\hline BD & 2 & 1.438 & 0.719 & 0.8548 & $\mathrm{NS}^{*}$ \\
\hline ABD & 2 & 14.449 & 7.224 & 8.5896 & $0,0002^{*}$ \\
\hline CD & 4 & 28.636 & 7.159 & 8.5119 & $0,0000^{*}$ \\
\hline ACD & 2 & 24.660 & 12.330 & 14.6599 & $0,0000^{*}$ \\
\hline BCD & 4 & 23.974 & 5.993 & 7.1260 & $0,0000^{*}$ \\
\hline ABCD & 252 & 211.950 & 0.841 & & \\
\hline Error & 287 & 1505.374 & & & \\
\hline Total & \multicolumn{5}{|l|}{} \\
\hline NS: insignificant, ${ }^{*}$ the difference is significant compared to 0.05 & & \\
\hline
\end{tabular}

According to the results of variance analysis glue type - ambient temperature $(\mathrm{BxD})$ and tree type - glue type - ambient temperature $(\mathrm{AxBxD})$ interactions were insignificant with $5 \%$ margin of error, while other factors and interactions were statistically significant. In order to determine among which groups the difference is important, Duncan test results are in Table 4-5-6-7-8-9-10-11-12.

\section{Duncan Test}

Table 4. Duncan Test Results of the Tree Type, Glue Type, Wood Preservation Type, Ambient Temperature Factors $\left(\mathrm{N} / \mathrm{mm}^{2}\right)$ for Shear Strength

\begin{tabular}{|c|c|c|c|}
\hline \multicolumn{2}{|l|}{ Factors } & $X_{\text {avg. }}$ & HG. \\
\hline \multirow{3}{*}{ Tree Species (A) } & Scotch Pine & 6.435 & $\mathrm{C}$ \\
\hline & Eastern Beech & 8.863 & $B$ \\
\hline & Sessile Oak & 10.18 & $A$ \\
\hline \multicolumn{4}{|c|}{ LSD: 0.2605} \\
\hline \multirow{2}{*}{ Type Of Glue (B) } & VTKA & 7.988 & $\mathrm{~B}$ \\
\hline & PVAC-D4 & 8.997 & A \\
\hline \multicolumn{4}{|c|}{ LSD: 0.2127} \\
\hline \multirow{3}{*}{ Type of Preservation (C) } & Impregnation & 8.691 & $A$ \\
\hline & Varnish & 8.875 & A \\
\hline & Control & 7.912 & $\mathrm{~B}$ \\
\hline \multicolumn{4}{|c|}{ LSD: 0.2605} \\
\hline \multirow{2}{*}{ Ambient Temperature (D) } & -15 & 8.960 & A \\
\hline & -30 & 8.025 & $\mathrm{~B}$ \\
\hline \multicolumn{4}{|l|}{ LSD: 0.2127} \\
\hline \multicolumn{4}{|c|}{$\mathrm{X}_{\text {avg.: }}$ Mean value (N/mm2), HG: Homogeneity group } \\
\hline
\end{tabular}


According to the Duncan test results of the tree type, glue type, wood preservation type, and ambient temperature factors for shear strength, the highest shear strength was obtained for the Sessile oak $\left(10,18 \mathrm{~N} / \mathrm{mm}^{2}\right)$ tree type. This result was $37 \%$ higher than the Scotch pine result, which was the type with the lowest shear strength.

PVAc-D4 glue had the highest shear strength among the glue types with an effectiveness $11 \%$ more than polyurethane-based VTKA glue, while in wood preservatives, there was no difference between impregnation and varnish process statistically. The varnish process was $12 \%$ more effective and shear strength decreases as ambient temperature goes down.

Table 5. Duncan Test Result on Tensile Adhesion Stress Parallel to Fibers (//) for Tree Species / Type of Glue (AxB) Interaction and Tree Species / Ambient

Temperature $(A x D)$ Interaction

\begin{tabular}{|c|c|c|c|c|c|c|c|c|c|}
\hline \multirow{2}{*}{$\begin{array}{l}\text { AxB } \\
\text { interaction }\end{array}$} & \multicolumn{2}{|c|}{ VTKA } & \multicolumn{2}{|c|}{ PVAC-D4 } & \multirow{2}{*}{$\begin{array}{l}\text { AxD } \\
\text { interaction }\end{array}$} & \multicolumn{2}{|c|}{$(-15 \circ C)$} & \multicolumn{2}{|c|}{$\left(-30^{\circ} \mathrm{C}\right)$} \\
\hline & $X_{\text {avg }}$ & $\mathrm{HG}$ & $\mathrm{X}_{\text {avg }}$ & $\mathrm{HG}$ & & $\mathrm{X}_{\text {avg }}$ & $H G$ & $\mathrm{X}_{\mathrm{avg}}$ & $H G$ \\
\hline Scotch Pine & 6.615 & $E$ & 6.255 & $E$ & $\begin{array}{l}\text { Scotch } \\
\text { Pine }\end{array}$ & 7.236 & $E$ & 5.633 & $F$ \\
\hline $\begin{array}{l}\text { Eastern } \\
\text { Beech }\end{array}$ & 8.052 & B & 9.674 & B & $\begin{array}{l}\text { Eastern } \\
\text { Beech }\end{array}$ & 9.160 & C & 8.566 & $D$ \\
\hline Sessile Oak & 9.297 & $A$ & 11.06 & $\bar{A}$ & $\begin{array}{l}\text { Sessile } \\
\text { Oak }\end{array}$ & 10.48 & $A$ & 9.876 & $B$ \\
\hline \multicolumn{5}{|c|}{ LSD value $=0.3684$} & \multicolumn{5}{|c|}{0.3684} \\
\hline
\end{tabular}

$\mathrm{X}_{\text {avg.: }}$ Mean value (N/mm2), HG: Homogeneity group

The Duncan test result for shear strength of the tree species / type of glue (AxB) interaction and tree species / ambient temperature (AxD) interaction is shown in table 5. According to this result, the highest shear strength was observed in Sessile oak with both glues $\left(9.297 \mathrm{~N} / \mathrm{mm}^{2}-11.06 \mathrm{~N} / \mathrm{mm}^{2}\right)$ and the lowest in Scotch pine with both glues $(6.615$ $\mathrm{N} / \mathrm{mm}^{2}-6.255 \mathrm{~N} / \mathrm{mm}^{2}$ ).

At the intersection of tree type and ambient temperature, the highest shear strength was observed in Sessile oak kept in a condition of $\left(-15^{\circ} \mathrm{C}\right)\left(10.48 \mathrm{~N} / \mathrm{mm}^{2}\right)$, and the lowest in Scotch pine kept in a condition of $\left(-30^{\circ} \mathrm{C}\right)\left(5.633 \mathrm{~N} / \mathrm{mm}^{2}\right)$.

Table 6. Duncan Test Result on Tensile Adhesion Stress Parallel to Fibers (//) for Tree Species / Type of Preservation (AxC) Interaction

\begin{tabular}{|l|c|c|c|c|c|c|}
\hline \multirow{2}{*}{$\begin{array}{c}\text { AxC } \\
\text { interaction }\end{array}$} & \multicolumn{2}{|c|}{ Impregnation } & \multicolumn{2}{c|}{ Varnish } & \multicolumn{2}{c|}{ Control } \\
\cline { 2 - 7 } & $\mathrm{X}_{\text {avg }}$ & HG. & $\mathrm{X}_{\text {avg }}$ & HG. & $\mathrm{X}_{\text {avg }}$ & HG. \\
\hline Scotch Pine & 6.657 & $\mathrm{E}$ & 7.351 & $\mathrm{D}$ & 5.296 & $\mathrm{~F}$ \\
\hline Eastern Beech & 8.443 & $\mathrm{C}$ & 9.448 & $\mathrm{~B}$ & 8.700 & $\mathrm{C}$ \\
\hline Sessile Oak & 10.97 & $\mathrm{~A}$ & 9.826 & $\mathrm{~B}$ & 9.740 & $\mathrm{~B}$ \\
\hline
\end{tabular}

The Duncan test result for shear strength of the tree species / type of preservation interaction $(\mathrm{AxC})$ is shown in Table 6. According to this result, the highest shear strength was observed in impregnation Sessile oak $\left(10.97 \mathrm{~N} / \mathrm{mm}^{2}\right)$ and the lowest in control Scotch pine samples $\left(5.296 \mathrm{~N} / \mathrm{mm}^{2}\right)$. 
Table 7. Duncan Test Result on Tensile Adhesion Stress Parallel to Fibers (//) for Type of Glue / Type of Preservation (BxC) Interaction

\begin{tabular}{|l|c|c|c|c|c|c|}
\hline \multirow{2}{*}{ BXC interaction } & \multicolumn{2}{|c|}{ Impregnation } & \multicolumn{2}{c|}{ Varnish } & \multicolumn{2}{c|}{ Control } \\
\cline { 2 - 7 } & $\mathrm{X}_{\text {avg }}$ & $\mathrm{HG}$ & $\mathrm{X}_{\text {avg }}$ & $\mathrm{HG}$. & $\mathrm{X}_{\text {avg }}$ & $\mathrm{HG}$. \\
\hline VTKA & 8.956 & $\mathrm{~B}$ & 7.925 & $\mathrm{D}$ & 7.084 & $\mathrm{E}$ \\
\hline PVAC-D4 & 8.425 & $\mathrm{C}$ & 9.825 & $\mathrm{~A}$ & 8.740 & $\mathrm{BC}$ \\
\hline LSD value $=0.3684$ & $\mathrm{X}_{\text {avg.: }}$ Mean value $(\mathrm{N} / \mathrm{mm} 2), \mathrm{HG}$ : Homogeneity group \\
\hline
\end{tabular}

The Duncan test result for shear strength of type of glue / type of preservation interaction $(\mathrm{BxC})$ is shown in Table 7 . According to this result, the highest shear strength was observed in PVAc-D4 glue varnished wood material $\left(9.825 \mathrm{~N} / \mathrm{mm}^{2}\right)$ and the lowest in VTKA glue control samples $\left(7.084 \mathrm{~N} / \mathrm{mm}^{2}\right)$.

Table 8. Duncan Test Result on Tensile Adhesion Stress Parallel to Fibers (//) for Type of Preservation / Ambient Temperature (CxD) Interaction

\begin{tabular}{|c|c|c|c|c|}
\hline \multirow[t]{2}{*}{ CxD interaction } & \multicolumn{2}{|c|}{$\left(-15^{\circ} \mathrm{C}\right)$} & \multicolumn{2}{|c|}{$\left(-30^{\circ} \mathrm{C}\right)$} \\
\hline & $\mathrm{X}_{\text {avg }}$ & $\mathrm{HG}$ & $\mathrm{X}_{\text {avg }}$ & $\mathrm{HG}$ \\
\hline Impregnation & 8.851 & B & 8.530 & $\mathrm{BC}$ \\
\hline Varnish & 9.563 & A & 8.186 & $\mathrm{C}$ \\
\hline Control & 8.465 & $\mathrm{C}$ & 7.359 & $\mathrm{D}$ \\
\hline
\end{tabular}

$\mathrm{X}_{\text {avg.: }}$ Mean value (N/mm2), HG: Homogeneity group

The Duncan test result for shear strength of type of preservation / ambient temperature $(\mathrm{CxD})$ interaction is shown in Table 8. According to this result, the highest shear strength was observed in varnished wood material kept in a condition of $\left(-15^{\circ} \mathrm{C}\right)$ $\left(9.563 \mathrm{~N} / \mathrm{mm}^{2}\right)$ and the lowest was observed in control samples with control samples in a condition of $\left(-30{ }^{\circ} \mathrm{C}\right)\left(7.359 \mathrm{~N} / \mathrm{mm}^{2}\right)$.

Table 9. Duncan Test Result on Tensile Adhesion Stress Parallel to Fibers (//) for Tree species / Type of Glue / Type of Preservation (AxBxC) Interaction

\begin{tabular}{|c|c|c|c|c|c|c|c|}
\hline \multirow{2}{*}{\multicolumn{2}{|c|}{ AxBXC interaction }} & \multicolumn{2}{|c|}{ Impregnation } & \multicolumn{2}{|c|}{ Varnish } & \multicolumn{2}{|c|}{ Control } \\
\hline & & $X_{\text {avg }}$ & HG. & $X_{\text {avg }}$ & HG. & $X_{\text {avg }}$ & HG. \\
\hline \multirow{2}{*}{ Scotch Pine } & VTKA & 7.884 & $\mathrm{FG}$ & 6.951 & $\mathrm{H}$ & 5.009 & I \\
\hline & PVAC-D4 & 5.429 & 1 & 7.751 & $F G$ & 5.583 & 1 \\
\hline \multirow{2}{*}{$\begin{array}{l}\text { Eastern } \\
\text { Beech }\end{array}$} & VTKA & 8.768 & $\mathrm{DE}$ & 7.371 & $\mathrm{GH}$ & 8.018 & $\mathrm{~F}$ \\
\hline & PVAC-D4 & 8.118 & $\mathrm{~F}$ & 11.52 & $A$ & 9.381 & $\mathrm{CD}$ \\
\hline \multirow{2}{*}{ Sessile Oak } & VTKA & 10.22 & $\mathrm{~B}$ & 9.452 & $\mathrm{C}$ & 8.224 & EF \\
\hline & PVAC-D4 & 11.73 & A & 10.20 & B & 11.26 & A \\
\hline
\end{tabular}

The Duncan test result for shear strength of tree species / type of glue / type of preservation $(\mathrm{AxBxC})$ interaction is shown in Table 9. According to this result, the highest shear strength was observed in impregnated $\left(11.73 \mathrm{~N} / \mathrm{mm}^{2}\right)$, control Sessile oak $(11.26$ $\left.\mathrm{N} / \mathrm{mm}^{2}\right)$ and varnished Eastern beech $\left(11.52 \mathrm{~N} / \mathrm{mm}^{2}\right)$, glued with PVAc-D4 glue, the lowest shear strength was observed in control Scotch pine $\left(5.009 \mathrm{~N} / \mathrm{mm}^{2}-5.583 \mathrm{~N} / \mathrm{mm}^{2}\right)$, impregnated Scotch pine glued with PVAc-D4 glue $\left(5.429 \mathrm{~N} / \mathrm{mm}^{2}\right)$. 
Table 10. Duncan Test Result on Tensile Adhesion Stress Parallel to Fibers (//) for Tree Species / Type of Preservation/ Ambient Temperature (AxCxD) Interaction

\begin{tabular}{|l|l|c|c|c|c|}
\hline \multirow{2}{*}{ AxCXD interaction } & \multicolumn{2}{|c|}{$\left(\mathbf{- 1 5 ^ { \circ } \mathbf { C } )}\right.$} & \multicolumn{2}{c|}{$\left(\mathbf{- 3 0}{ }^{\circ} \mathbf{C}\right)$} \\
\cline { 2 - 6 } & $X_{\text {avg }}$ & HG. & $X_{\text {avg }}$ & HG. \\
\hline \multirow{3}{*}{ Scotch Pine } & Impregnation & 7.534 & $\mathrm{H}$ & 5.780 & $\mathrm{~J}$ \\
\cline { 2 - 6 } & Varnish & 7.970 & $\mathrm{GH}$ & 6.733 & $\mathrm{I}$ \\
\cline { 2 - 6 } & Control & 6.206 & $\mathrm{IJ}$ & 4.386 & $\mathrm{~K}$ \\
\hline \multirow{2}{*}{$\begin{array}{l}\text { Eastern } \\
\text { Beech }\end{array}$} & Impregnation & 8.611 & $\mathrm{EF}$ & 8.275 & $\mathrm{FG}$ \\
\cline { 2 - 6 } & Varnish & 9.909 & $\mathrm{C}$ & 8.986 & $\mathrm{DE}$ \\
\cline { 2 - 6 } & Control & 8.961 & $\mathrm{DE}$ & 8.439 & $\mathrm{EFG}$ \\
\hline \multirow{3}{*}{ Sessile Oak } & Impregnation & 10.41 & $\mathrm{BC}$ & 11.54 & $\mathrm{~A}$ \\
\cline { 2 - 6 } & Varnish & 10.81 & $\mathrm{~B}$ & 8.841 & $\mathrm{DEF}$ \\
\cline { 2 - 6 } & Control & 10.23 & $\mathrm{BC}$ & 9.251 & $\mathrm{D}$ \\
\hline \multicolumn{2}{|l|}{ LSD value $=0.6382 \quad X_{\text {avg.: Mean value (N/mm2), HG: Homogeneity group }}$} \\
\hline
\end{tabular}

The Duncan test result for shear strength of tree species / type of preservation/ ambient temperature $(\mathrm{AxCxD})$ interaction is shown in Table 10. According to this result, the highest shear strength was observed in impregnated Sessile Oak kept in a condition of $\left(-30{ }^{\circ} \mathrm{C}\right)\left(11.54 \mathrm{~N} / \mathrm{mm}^{2}\right)$ and the lowest in control Scotch pine kept in a condition of (-30 $\left.{ }^{\circ} \mathrm{C}\right)\left(4.386 \mathrm{~N} / \mathrm{mm}^{2}\right)$.

Table 11. Duncan Test Result on Tensile Adhesion Stress Parallel to Fibers (//) for the Type of Glue / Type of Preservation/ Ambient Temperature (AxCxD) Interaction

\begin{tabular}{|c|c|c|c|c|c|}
\hline \multirow{2}{*}{\multicolumn{2}{|c|}{ BXCXD interaction }} & \multicolumn{2}{|c|}{$\left(-15^{\circ} \mathrm{C}\right)$} & \multicolumn{2}{|c|}{$\left(-30^{\circ} \mathrm{C}\right)$} \\
\hline & & $X_{\text {avg }}$ & HG. & $X_{\text {avg }}$ & HG. \\
\hline \multirow{3}{*}{ VTKA } & Impregnation & 8.992 & $C D$ & 8.921 & $C D$ \\
\hline & Varnish & 9.114 & $C D$ & 6.735 & $G$ \\
\hline & Control & 7.522 & $\mathrm{~F}$ & 6.645 & $G$ \\
\hline \multirow{3}{*}{ PVAC-D4 } & Impregnation & 8.710 & D & 8.140 & $E$ \\
\hline & Varnish & 10.01 & A & 9.637 & $A B$ \\
\hline & Control & 9.408 & $B C$ & 8.072 & $E$ \\
\hline
\end{tabular}

The Duncan test result for shear strength of the glue type/wood preservation type/ ambient temperature interaction $(\mathrm{BxCxD})$ interaction is shown in Table 11. According to this result, the highest shear strength was observed in PVAc-D4 glue varnished wood material kept in a condition of $\left(-15{ }^{\circ} \mathrm{C}\right)\left(10.01 \mathrm{~N} / \mathrm{mm}^{2}\right)$, and the lowest was in control samples varnished and impregnated with VTKA glue kept in a condition of $\left(-30^{\circ} \mathrm{C}\right)(6.735$ $\mathrm{N} / \mathrm{mm}^{2}-6.645 \mathrm{~N} / \mathrm{mm}^{2}$ ).

The Duncan test results for shear strength of the tree species/glue type/wood preservation type/ ambient temperature interaction $(\mathrm{AxBxCxD})$ interaction are shown in Table 12. According to this result, the highest shear strength was observed in the impregnated Sessile oak in general and the lowest in the control sample of the VTKA glue Scotch pine. 
Table 12. Duncan Test Result on Tensile Adhesion Stress Parallel to Fibers (//) for Tree Species / Type of Glue / Type of Preservation/ Ambient Temperature (AxBxCxD) Interaction

\begin{tabular}{|c|c|c|c|c|c|c|c|}
\hline \multirow{2}{*}{\multicolumn{2}{|c|}{$\begin{array}{l}\text { AxBxCxD } \\
\text { interaction }\end{array}$}} & \multicolumn{2}{|c|}{ Impregnation } & \multicolumn{2}{|c|}{ Varnish } & \multicolumn{2}{|c|}{ Control } \\
\hline & & \multirow{2}{*}{$\begin{array}{c}\left(-15^{\circ} \mathbf{C}\right) \\
X_{\text {avg }}\end{array}$} & \multirow{3}{*}{$\begin{array}{c}\left(-30^{\circ} \mathbf{C}\right) \\
X_{\text {avg }} \\
6.882 \\
K L\end{array}$} & \multirow{3}{*}{$\begin{array}{c}\mathbf{( - 1 5 ^ { \circ } \mathbf { C } )} \\
X_{\text {avg }} \\
7.836 \\
\text { HIJ }\end{array}$} & \multirow{3}{*}{$\begin{array}{c}\left(-30^{\circ} \mathbf{C}\right) \\
X_{\text {avg }} \\
6.066 \\
L\end{array}$} & \multirow{3}{*}{$\begin{array}{c}\left(-15^{\circ} \mathbf{C}\right) \\
X_{\text {avg }} \\
6.064 \\
L\end{array}$} & \multirow{3}{*}{$\begin{array}{c}\left(-30^{\circ} \mathbf{C}\right) \\
X_{\text {avg }} \\
3.954 \\
M\end{array}$} \\
\hline \multirow{3}{*}{$\begin{array}{l}\text { Scotch } \\
\text { Pine }\end{array}$} & & & & & & & \\
\hline & VTKA & $\begin{array}{l}8.886 \\
\text { EFG }\end{array}$ & & & & & \\
\hline & PVAC-D4 & $\begin{array}{c}6.181 \\
L\end{array}$ & $\begin{array}{c}4.677 \\
M\end{array}$ & $\begin{array}{l}8.104 \\
\text { GHIJ }\end{array}$ & $\begin{array}{c}7.399 \\
\text { JK }\end{array}$ & $\begin{array}{c}6.347 \\
L\end{array}$ & $\begin{array}{c}4.819 \\
M\end{array}$ \\
\hline \multirow{2}{*}{$\begin{array}{l}\text { Eastern } \\
\text { Beech }\end{array}$} & VTKA & $\begin{array}{l}8.945 \\
E F G\end{array}$ & $\begin{array}{l}8.591 \\
\text { FGH }\end{array}$ & $\begin{array}{c}8.521 \\
\text { FGH }\end{array}$ & $\begin{array}{c}6.220 \\
L\end{array}$ & $\begin{array}{l}7.602 \\
\text { IJK }\end{array}$ & $\begin{array}{l}8.434 \\
\text { FGHI }\end{array}$ \\
\hline & PVAC-D4 & $\begin{array}{l}8.276 \\
\text { FGHIJ }\end{array}$ & $\begin{array}{c}7.959 \\
\text { HIJ }\end{array}$ & $\begin{array}{c}11.30 \\
A B\end{array}$ & $\begin{array}{c}11.75 \\
A\end{array}$ & $\begin{array}{c}10.32 \\
C D\end{array}$ & $\begin{array}{l}8.444 \\
\text { FGHI }\end{array}$ \\
\hline \multirow{2}{*}{$\begin{array}{l}\text { Sessile } \\
\text { Oak }\end{array}$} & VTKA & $\begin{array}{c}9.144 \\
\text { EF }\end{array}$ & $\begin{array}{c}11.29 \\
A B\end{array}$ & $\begin{array}{l}10.98 \\
A B C\end{array}$ & $\begin{array}{c}7.920 \\
\text { HIJ }\end{array}$ & $\begin{array}{l}8.899 \\
\text { EFG }\end{array}$ & $\begin{array}{l}7.549 \\
\text { IJK }\end{array}$ \\
\hline & PVAC-D4 & $\begin{array}{c}11.67 \\
\mathrm{~A}\end{array}$ & $\begin{array}{c}11.78 \\
A\end{array}$ & $\begin{array}{l}10.64 \\
B C D\end{array}$ & $\begin{array}{c}9.761 \\
\mathrm{DE}\end{array}$ & $\begin{array}{c}11.56 \\
\mathrm{~A}\end{array}$ & $\begin{array}{l}10.95 \\
\mathrm{ABC}\end{array}$ \\
\hline
\end{tabular}

\section{DISCUSSION}

In this study, the changes that may occur in the shear strength of the wood preservative material at low temperatures were determined. Considering the air-dry density values in general, it was higher than the solid wood material. It is seen that the lamination, which is done with different types of glue, differs in air-dry density compared to solid samples. The reason for this is that each of the adhesives involved in the lamination has differing amounts of solid materials. Furthermore, it is observed that these density values coincide with the values stipulated in various furniture standards. Considering the retention rates, the highest retention rate was achieved in Scotch pine laminated with VTKA glue, and the lowest retention rate was achieved in Eastern beech laminated with PVAc-D4 glue. The reason for achieving the highest retention rate in Scotch pine lamination was that the density of Scotch pine is lower than other wood types. It can be said that the passage pairs that allow the longitudinal flow of coniferous trees are open and the viscosity of the VTKA glue used in lamination is high and provides superficial adhesion. Therefore, it cannot penetrate the depths of the lamination layer and prevent the movement of the impregnation solution inside the tree. This situation is in line with the results of the study conducted by Örs et al. (1999).

For the shear strength of laminated elements according to the tree type, the highest shear strength was achieved in oak lamination $\left(10,18 \mathrm{~N} / \mathrm{mm}^{2}\right)$, while the lowest was achieved in Scotch pine lamination $\left(6,435 \mathrm{~N} / \mathrm{mm}^{2}\right)$. It can be said that the high adhesion stress in tensile adhesion stress parallel to fibers in oak lamination is due to the occurrence of mechanical adhesion in addition to specific adhesion on oak veneer surfaces. This situation coincides with the results of the studies conducted with Eastern beech, Sessile oak, and Scotch pine by (Altınok et al. 2009).

The highest shear strength in terms of glue varieties was achieved when using PVAc-D4 glue. The results of the experiment are closely related to some studies in the literature. In his study, Doruk (2009) laminated 2 mm thick Eastern beech, Sessile oak, 
Scotch pine, and chestnut veneer using PU, PVAc-D4, MF, and RF glues, and managed natural and artificial aging with the use of wood preservatives. He found the result of $\mathrm{RF}>\mathrm{MF}>\mathrm{PVAc}-\mathrm{D} 4>\mathrm{PU}$ on tensile adhesion stress parallel (//) to fibers.

It was determined that there was no statistically significant difference between the varnish treatment and the impregnation process, with $12 \%$ and $10 \%$ effectiveness, respectively. This situation suggest that the varnish and impregnation process creates a barrier against cold, protecting the wood material surface and especially the wood glue line joint.

Regarding the effect of ambient temperature, shear strength has been observed to decrease as the temperature goes down. This result shows similarities to the study of Wang et al. (2015), who studied the "impact of cold temperatures on the shear strength of Norway spruce joints glued with different adhesives" and a possible reason for this in the cold climate could be that the shear strength of the wood material becomes lower at the same time as the joint samples become more brittle and more sensitive to small variations in geometry and the testing procedure (Wang et al. 2015).

\section{CONCLUSIONS}

1. Although the lamination technique provides a significant advantage in the construction of wooden structures to be used in external environments, wood lamination must be reinforced with wood-preservative substances to maintain its strength against the negative effects of the external environment.

2. When wood-preservative substances are not used, the adhesion stress decreases as the ambient temperature decreases, and therefore it must necessarily be reinforced with appropriate preservatives.

3. As a result of this study, especially in the regions with cold climate conditions, it is recommended that wood laminated construction elements to be used outdoors can be preserved against external factors such as extreme cold, rain, UV sunlight, by gluing with oak veneer PVAc-D4 glue and varnishing with synthetic-based varnish. This varnishing will also provide an aesthetic look. In addition, varnishing is recommended, as impregnation is difficult and expensive for large building materials.

\section{REFERENCES CITED}

Altınok, M., Sögütlü, C., and Kahraman, N. (2009). "Determination of bonding performance of laminated veneer elements produced in vacuum membrane press," AKÜ Journal of Science 51-59.

ASTM-D 1413-07 (2007). "Standard test method of testing wood preservatives by laboratory soilblock cultures," ASTM International, West Conshohocken, PA, USA.

Ayrilmis, N., Buyuksari, U., and As, N. (2010). "Bending strength and modulus of elasticity of wood-based panels at cold and moderate temperatures," Cold Regions Science and Technology 63(1-2), 40-43.

Bekhta, P, and Marutzky R. (2007). "Bending strength and modulus of elasticity of particleboards at various temperatures," Holz Als Roh-Und Werkstoff 65(2), 163-165. BS EN 204 (1991). "Non-structural adhesives for joining of wood and derived timber 
products," British Standards Institution, London.

Clauss, S., Joscak, M., and Niemz, P. (2011). "Thermal stability of glued wood joints measured by shear tests," Eur. J. Wood Prod. 69(1), 101-111. DOI: 10.1007/s00107010-0411-4

Doruk, Ş. (2009). The Determination of the Effect of Varnish and Impregnated Proceedings of Laminated Wooden Materials on Ageing, Ph.D. Dissertation, Gazi University, Institute of Science and Technology, Ankara.

Drake, G., Berry, M., and Schroeder, D. (2015). "Effect of cold temperatures on the shear behavior of glued laminated beams," Cold Regions Science and Technology 112, 4550.

Falkner, H., and Teutsch, M. (2006). "Load-carrying capacity of glued laminated wood girders under temperature influence," Bautechnik 83(6), 391-393. DOI: 10.1002/bate.200610032

Frangi, A., Fontana, A., and Mischler, A. (2004). "Shear behavior of bond lines in glued laminated timber beams at high temperatures," Wood Sci. Technol. 38(2), 119-126. DOI: 10.1007/s00226-004-0223-y

Kainz, J., and Ritter, M. (1998). "Effect of cold temperatures on stress-laminated timber bridge deck," in: Proceedings of the $5^{\text {th }}$ World Conference on Timber Engineering Vol. 2, J. Natterer and J. L. Sandoz (eds.), Swiss Federal Institute of Technology Lausanne, Montreux, Switzerland, pp. 42-49.

Olsson, T., Megnis, M., Varna, J., and Limdberg, H. (2001). "Measurement of the uptake of linseed oil in pine by the use of an X-ray microdensitometry technique," Journal of Wood Science 47, 275-281.

Petrovic, J. J. (2003). "Mechanical properties of ice and snow," Journal of Materials Science 38(1), 1-6.

Schmidt, R. A., and Pomeroy, J. W. (1990). "Bending of a conifer branch at subfreezing temperatures - Implications for snow interception," Canadian Journal of Forest Research-Revue Canadienne De Recherche Forestiere 20(8), 1250-1253.

Suzuki, S., and Saito, F. (1987). "Effects of environmental factors on the properties of particleboard. 1. Effect of temperature on bending properties," Mokuzai Gakkaishi 33(4), 298-303.

Szmutku, M. B., Campean, M., and Porojan, M. (2013). "Strength reduction of spruce wood through slow freezing," European Journal of Wood and Wood Products 71(2), 205-210.

TS EN 205 (2004). "Adhesives - Wood adhesives for nonstructural applications Determination of tensile shear strength of glued attachments," Turkish Standards Institute, Ankara, Turkey.

TS EN 322 (1999). "Wood-based panels - Determination of moisture content," Turkish Standards Institute, Ankara, Turkey.

Var, A. A. (2001). "Reduction by paraffin wax/linseed oil mixture of water up taken in wooden materials," S.D.U. Forestry Faculty Review. A(2), 97-110.

Wacker, J. P. (2003). Cold Temperature Effects on Stress-Laminated Timber Bridges-A Laboratory Study (Res. Pap. FPL-RP-605), U.S. Department of Agriculture Forest Products Laboratory, Madison, WI.

Wacker, J. P. (2009). "Performance of stress-laminated timber highway bridges in cold climates," in: Proceedings of the $14^{\text {th }}$ Conference on Cold Regions Engineering, Duluth, MN, USA, pp. 637-649.

Wang, X., Olle, H., Bror, S., Sigurdur, O., Hui, W., and Peter, N. (2015). "Impact of cold 
temperatures on the shear strength of Norway spruce joints glued with different adhesives," Eur. J. Wood Prod. 73(2), 225-233. DOI: 10.1007/s00107-015-0882-4

Wang, X., Hagman, O., Sundqvist, B., Ormarsson, S., Wan, H., and Niemz, P. (2016). "Shear strength of Scotch pine wood and glued joints in a cold climate," BioResources 11(1), 944-956. DOI: 10.15376/biores.11.1-944-956

Article submitted: October 5, 2020; Peer review completed: November 27, 2020; Revised version received: March 8, 2021; Accepted: March 9, 2021; Published: March 22, 2021. DOI: 10.15376/biores.16.2.3377-3390 